\title{
Assessment of commercial feedlot finishing practices at eastern Shoa, Ethiopia
}

\author{
Tsegay Teklebrhan*, Mengistu Urge \\ College of Agriculture, School of Animal and Range Sciences, Haramaya University, Dire Dawa, Ethiopia; \\ *Corresponding Author: ttmamy06@gmail.com
}

Received 24 July 2013; revised 25 August 2013; accepted 12 September 2013

Copyright (c) 2013 Tsegay Teklebrhan, Mengistu Urge. This is an open access article distributed under the Creative Commons Attribution License, which permits unrestricted use, distribution, and reproduction in any medium, provided the original work is properly cited.

\section{ABSTRACT}

This study was conducted to characterize and identify husbandry practice and major constraints of commercial feedlot industries in the study area. Forty eight commercial feedlot farms were used to collect data. Data were analyzed using Statistical Package for the Social Sciences (SPSS). The results showed that, livestock species such as cattle, shoat and camels were used in commercial fattening though significant variation in demand among species. Cattle had got the highest acceptance in feedlot industries followed by shoat, however, camel and swine had least preference. All cattle breeds were granted equal requirement by domestic market. However, there is variation in demand among cattle breeds for export market. Boran was the most preferred cattle breed compared to the rest of cattle by the importers. Uncastrated bull demanded for export market however, castrated and female cattle were not used for export markets. Pastoralists were the potential supplier of feeder livestock followed by small holders to feedlot industries. Teff straw was predominantly used roughage feed in most of commercial feedlot farms and agro-industrial by-products as a source of concentrate. However, sorghum and maize grains were utilized by very few farms. Vitamin and mineral supplementation were not often available except common salt in all feedlot rations. Market was noted as the most potential constraints followed by feed and type of livestock coming to the markets in the commercial feedlot industries. The study suggested that, government and other development partners should provide and improve all services to pastoralists or producers in an organized way at their local- ities to ensure sustainable supply of livestock to the market.

Keywords: Constraints; Fattening; Livestock

\section{INTRODUCTION}

Ethiopia owned a large livestock population [1]. It is home to Africa's largest livestock population, and is Africa's top livestock producer and exporter (principally to the Middle East). Ethiopia is the world's tenth largest producer of livestock, and the livestock sector represents about one-fifth of its gross domestic product (GDP). The government has indicated a strong interest in increased foreign investment in the agriculture sector, among others, commercial breeding and production of meat, milk, and eggs. Although domestic demand for animal products in Ethiopia is increasingly driven by the urban middle and upper class, export potential is a key force encouraging expansion and intensification of livestock production. In 2008, Ethiopia exported nearly 300,000 live animals primarily cattle as well as 6000 metric tons of meat products, earning about US \$ 56 million. In 2009, the government sought to double the previous year's income from live animal exports planned to $\$ 40$ million and raise the number of animals exported to 400,000, indicating that government is keen to foster an upward trend. For 2009-2010, it set targets for export of meat products of nearly 16,000 metric tons, a nearly four-fold increase over the 2007 level, while the contribution of the livestock industry to the country's total exports was currently low compared to its potential. This is due to the fact that livestock production has mostly been subsistence oriented and characterized by very low reproductive and production performance which is not even enough to meet the domestic requirement of community for animal protein. This is because of major limiting factors on farm conditions, among others, feed shortage, low genetic 
potential and diseases.

However, market oriented livestock production has been gradually emerging in very recent years. The government of Ethiopia is trying to expand sector by motivating investors to meet projected increase in demand from both export and domestic markets. Export of meat and live animals that can contribute to market-led economic growth and country is focused by the government. Accordingly, live animal export accounts for $4.5 \%$, meat and meat products $1.7 \%$, from the total export potential of the country [1]. The goal is to increase annual export of live animal and meat from Ethiopian cattle, sheep and goats by about three fold though; the markets are sophisticated and extremely competitive for high quality product. Feedlot provides the means to maximize the opportunities offered by these markets for a consistent supply of high quality product for the particular needs of the market. The continuing growth of the feedlot sector is necessary to meet projected increase in demand from both export and domestic markets. However, such growth must progress according to community expectations and requirements to develop and maximize the profit from the livestock business.

Information about commercial fattening or feedlot practices and its constraints is important for researchers, policy makers to take serious measures and suggest possible technologies to improve the productivity of the sector and hence maximize its contribution to the total Gross Domestic Product (GDP) or economy of the country. However, there is no documented information on fattening practices of commercial feedlot and their challenges in Ethiopia. Therefore, the paper is designed to characterize and identify husbandry practice and major constraints of commercial feedlot industries in the study area.

\section{MATERIALS AND METHODS}

\subsection{Description of Study Area}

The study was conducted in Adama, Methara and Mojo towns found in east Shoa Zone, Oromiya Regional State, Ethiopia. It is located at about an altitude of 1650 meters above sea level and its annual temperature ranges from $13.9^{\circ} \mathrm{C}-29^{\circ} \mathrm{C}$. The mean annual rainfall of the area is $1024 \mathrm{~mm}$. The livestock population of the area was estimated to be 70,622 cattle, 36,142 sheep, 42,968 goats and 2193 equines [2].

\subsection{Sampling and Data Collection}

Three towns Adama, Methara and Mojo were purposely selected based on their potential for feedlot Industry, from which a total of 48 feedlot farms, were randomly selected and used for the study. Primary data were collected using pre tested semi-structured questionnaire through interview and discussion with the feedlot opera- tors. In addition, secondary information was gathered from literature and Central Statistical Agency (CSA) reports. Physical observation of commercial farms was also used as an instrument to collect data during the study.

Data on the types of livestock species used for feedlot, pattern of livestock preferences, breeds of cattle and market demand, value chain of marketing, fattening cycle and duration, feed resources feeding procedure and constraints and housing of commercial fattening were collected from the commercial fatteners.

\subsection{Statistical Analysis}

Data were subjected to Statistical Package for the Social Sciences [3] and analyzed using simple descriptive statistics such as frequency and percentage.

\section{RESULTS AND DISCUSSION}

\subsection{Commercial Fattening and Livestock Species}

Commercial feedlot is a confined yard area with watering and feeding facilities where livestock are completely handled or mechanically fed for the purpose of production. Number of heads that would fatten at a cycle was variable across the farms depending on the capacity of the farms. From that reason, commercial feedlots finished relatively large number of animals at a time than small scale fattening. Accordingly, most of commercial farms had 100 - 500 heads followed by 1000 - 1500 heads at a time as shown in Table 1.

Livestock species such as cattle, shoat and camels are used in commercial fattening and then exported as live animal and meat however; cattle breeds were usually used for fattening in the study areas as listed in Table $\mathbf{1 .}$

Table 1. Livestock species and type of cattle breed used for commercial feedlot.

\begin{tabular}{lcc}
\hline Items & N & Percentage \\
\hline No of livestock head & 42 & \\
100 - 500 & 6 & 87.5 \\
1000 - 1500 & & 12.5 \\
Livestock species & 39 & 81.25 \\
Boran & 5 & 10.42 \\
Bale and Arsi & 1 & 2.08 \\
Hararghe Highlandand Ogaden Cattle & 3 & 6.25 \\
Shoat and camel & 48 & 100 \\
Total & & \\
Age of animal purchased & 45 & 93.75 \\
4 - 6 years & 3 & 6.25 \\
Not known & 48 & 100 \\
Total & & \\
\hline
\end{tabular}

$\mathrm{N}=$ Number of Respondents. 
Among the cattle breeds, feed lot operators showed highest preference on Boran followed by Bale and Arsi cattle. In consistent to this study, [4] reported that the main live animal species exported include cattle, sheep, goats, and camels. In addition, discussants revealed that Boran cattle have docile temperament, short horn and efficient as well as better in carcass conformation, which is attribute to be breed of demand for export. This result is consistent to the reports of [5]. However, Hararghe Highland and Ogaden cattle breeds had least acceptance for commercial fattening in the study area. This variation on the cattle breed requirement might be associated with available export market demands and fattening performance of the breeds. For example, discussants argued that Hararghe Highland shrunk its body weight when came from its original place (highland) to the fattening unit (lowland). Likewise, most of feedlot fatteners during discussion also noted that they knew nothing about the performance of Ogaden cattle. All fatteners agreed that uncastrated bull was required for export market as compared to castrated cattle (steer and stag). In this regard, fatteners explained that the export market demand is lean meat than that of castrated from which fatty meat with high fat coverage is actually produced. In all commercial fattening areas, male livestock was preferred than female. This is because of male having better carcass conformation compared to female cattle. In addition discussants also strongly argued that export of female is impossible. This study also showed that $93.75 \%$ respondents noted that bulls were purchased at about age of 4 - 6 years.

\subsection{Pattern of Preferences of Livestock Species in Commercial Feedlot Industries}

All livestock species were preferred for fattening industry though there was significant variation among farms on degree of choices as shown in Table 2. For that reason, $89.58 \%$ feed lot farms consider cattle as their first choice for commercial fattening. Physical observation also confirmed that except the three farms in Methhara all farms of the study areas were only engaged in cattle fattening enterprises. All discussants, agreed that fatten- ing of cattle was advantageous because of low mortality, better tolerance for some diseases, frequent

Table 2. Ranking of livestock species for commercial fattening.

\begin{tabular}{cccccccccc}
\hline Livestock & $\mathrm{N}$ & 1st & $\mathrm{P}$ & 2nd & $\mathrm{P}$ & 3rd & $\mathrm{P}$ & 4th & $\mathrm{P}$ \\
\hline Cattle & 45 & 43 & 89.5 & 2 & 4.1 & 0 & 0 & 0 & 0 \\
Shoat & 37 & 2 & 4.1 & 24 & 50.0 & 11 & 22.9 & 0 & 0 \\
Cmel & 25 & 3 & 6.2 & 12 & 25.0 & 10 & 20.8 & 0 & 0 \\
Pig & 11 & 0 & 0 & 0 & 0 & 0 & 0 & 11 & 22.9 \\
\hline N = Number of Respondents; $\mathrm{P}=$ Percentage.
\end{tabular}

availability at the market place, best suitable and manageable and, required small space particularly as compared to camel. Shoat was found as the second important livestock species for commercial fattening by most of the feedlot farms in the study area. For that reason, the discussants elaborated that, shoat required low amount of feed and space as compared to cattle and camel. However, shoats had higher mortality and rapid lost or shrink of live weight particularly during long distance travel for long time from the country to export destination because of in appropriate transport systems.

This study also showed that camel was preferred as third important livestock used for fattening and highest requirement in the export market. However, most of feedlots retained camel for short period of time until it is exported. This is because camel requires large area of land and the feeding habits of camel which needs browses rather than stall feeding. This study confirmed that pig was least required for commercial fattening by most of the farms, though it is considered as the first choice of most of the Asian and European countries involved in fattening enterprises. This may be due to lack of knowledge on the importance of this livestock and mainly because of socio-cultural and religious barriers [6]. In addition some discussants believed that swine is a livestock species required large amount of feed per unit of gain and never satisfied and domestic market demand problems. However, it is known that swine is rapid growing, efficient feed converter and even fed on most of least cost feeds and organic wastes.

\subsection{Fattening Cycles and Duration in Commercial Feedlot}

Almost all fattening farms finish the bull for about an average of 3 - 4 months in Table 3 . In agreement to this study, previous result reported a range of 80 to 145 days to finish steers [7]. However, few farms did finish the bull at 6 months and very few at 1 month.

Generally, feedloters agreed on the strong relation between age of bull at purchase and for how long the bull will be retained on fattening. Accordingly, bull entered as feeder at relatively younger age will retain for long time and the reverse is true for relatively older bull. Fattening cycles of beef cattle is important to secure continued

Table 3. Fattening cycles and duration of cattle.

\begin{tabular}{cccccc}
\hline Fattening duration & $\mathrm{N}$ & $\mathrm{P}$ & Fattening cycle & $\mathrm{N}$ & $\mathrm{P}$ \\
\hline 3 - 4 moths & 42 & 87.5 & Two & 9 & 18.8 \\
6 months & 5 & 10.4 & Three & 30 & 62.5 \\
1 months & 1 & 2.0 & Four & 9 & 18.8 \\
Total & 48 & 100 & Total & 48 & 100 \\
\hline
\end{tabular}

$\mathrm{N}=$ Number of Respondents; $\mathrm{P}=$ Percentage. 
supply of meat for consumption as well as local and export markets. Most of the respondents engaged in the fattening venture agreed on three cycles of fattening per year but very few feedlot fatteners fattened two and four time per year as reported in Table 3. Discussants declared that, the reason of variation in fattening cycles among feedlots were fattening duration, types of feed, market situation and weight of cattle.

\subsection{Effect of Breed, Sex and Gender of Cattle on Market Demand}

All cattle breeds are preferred for export market though; there is variation in demand among breeds as shown in Table 4. Accordingly, most of the feedlot operators exported Boran cattle than the rest of cattle breeds. This is the reflection of the inherent quality of the specified breed in that it possessed docile temperament, heavier live weight, better feed conversion efficiency and lean carcass compared to the rest of the cattle breeds. However, all cattle breeds had equal benefit for the domestic markets as shown in Table 4.

Feedloters mentioned cattle that were not fit for export markets were used for domestic market. Generally the export volume of the country is limited to very few destination countries principally to Middle East. This may be associated with international standard quality of the product and demand of importers. In addition, some of the trade and zoonotic diseases; foot and mouth disease, contagious bovine pleuropheumonia (CBPP), Peste des petits ruminants (PPR), lumpy skin disease (LSD), contagious caprine pleuropneumonia (CСPP), sheep and goat pox and brucellosis [8] are not controlled in the

Table 4. Effect of Breed, sex and gender of cattle on market demand.

\begin{tabular}{lcc}
\hline Export market & N & Percentage \\
\hline Boran & 29 & 60.4 \\
Boran, Bale, Arsi and Hararghe Highland & 16 & 33.3 \\
All breeds & 3 & 6.2 \\
\hline Domestic market & & \\
\hline All breeds & 48 & 100 \\
\hline Value addition & & \\
\hline Yes & 0 & 0 \\
No & 48 & 100 \\
\hline Sex class & & \\
\hline Castrated & 0 & 0 \\
Un-cast rated & 48 & 100 \\
\hline Gender & & \\
\hline Male & 48 & 100 \\
Female & 0 & 0 \\
\hline
\end{tabular}

$\mathrm{N}=$ Number of Respondents. country. Moreover, discussants argued that long horned cattle breed like Afar were not required by the Arab importers.

With regard to value addition and diversification of products, none of the feedlot farms were engaged in value addition, though government is showing commitment to support and encourage the business. However, all feedloters have an interest to add value and diversify the export commodities from the fattened livestock for the future rather than exporting of only live cattle.

\subsection{Value Chain of Livestock Marketing in Commercial Feedlot}

Pastoralists were the potential supplier of livestock followed by smallholders to feedlot industries in study area as shown in Figure 1. Respondents noted that usually marketing of livestock in commercial feedlot followed the trend as indicated by the block arrows staring from producers up to destinations. Accordingly, small local trades bought small number of livestock at the farm gate and in turn sold to the other intermediate actors in the chain and continued in such away. Similarly, [9] reported same role of pastoralists and small holder farmers at livestock marketing.

However, in rare cases livestock marketing followed a different and short path that is a direct purchase of livestock from producer by the commissions or larger traders and feedlot operators. Similarly, the marketing root was also organized from the producers to the farmer union/ other cooperatives and this in turn to fattening farms as indicated in the direct line arrows of Figure 1. This seems to be best alternative to minimize and avoid unprofitable transactions in the chain and ensure fair and legitimate market systems.

\subsection{Feed Resources for Commercial Feedlots}

All commercial feedlots were depending on purchased feed sources for fattening because of shortage of land for feed production as shown in Table 5. Accordingly, native grass hay was purchased from Sululta, and straws from Welenchiti. Agro-industrial by products was also bought from the factories in and around East Shewa. This could be mainly because almost all commercial farms were found around this areas and this gives them easy access to agro-industrial byproducts which form a major portion of the concentrate mix fed to feeder livestock.

\subsubsection{Roughage}

Roughage feeds are characterized by relatively higher fiber content and lower energy and protein contents than concentrates. The source of roughage used for commercial feedlot includes crop reside (teff straw, wheat straw) and native grass hay. In consistent to this result, $[10,11]$ 


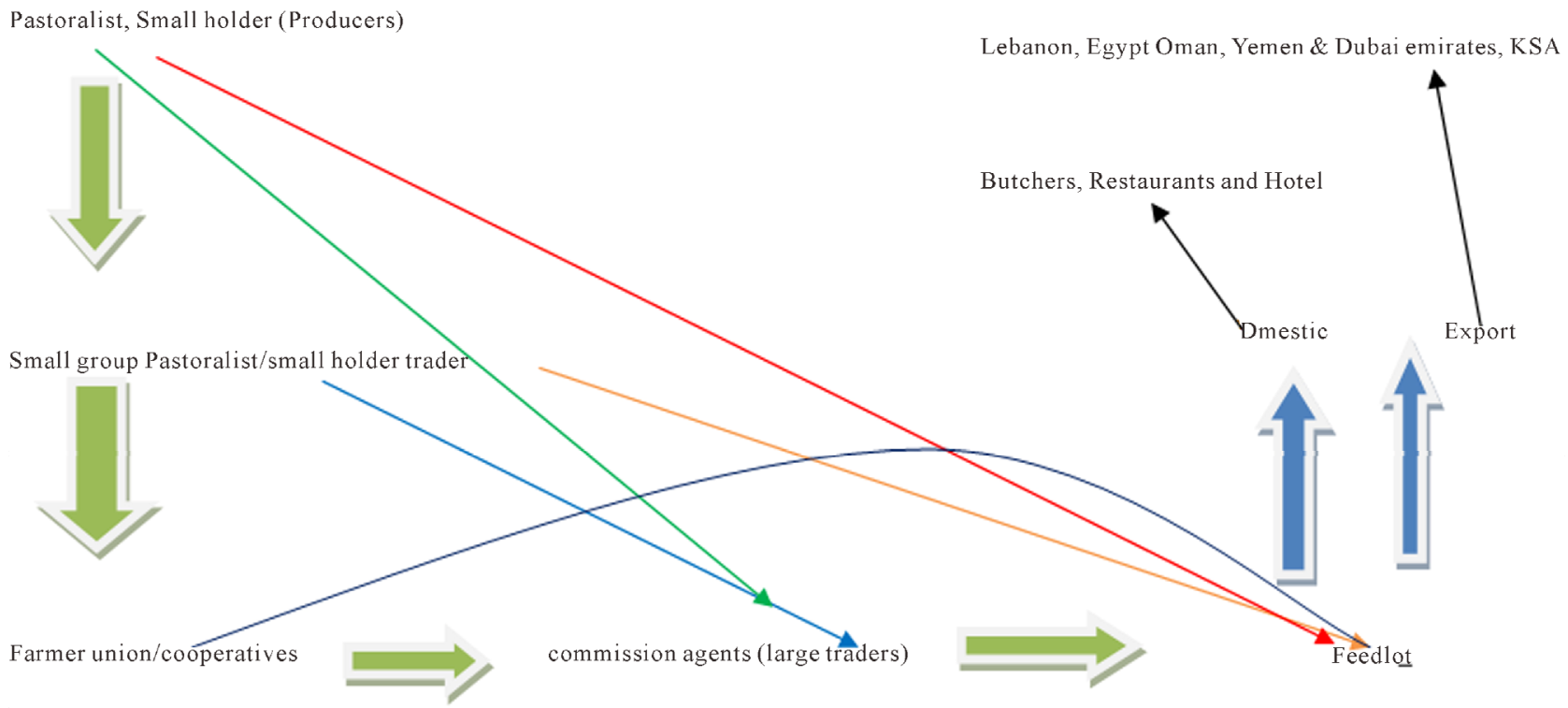

Figure 1. Flow chart of value chain of commercial feedlot marketing (interview, 2013).

Table 5. Feed stuffs used for commercial fattening.

\begin{tabular}{|c|c|c|}
\hline Feed resources & $\mathrm{N}$ & Percentage \\
\hline purchased & 48 & 100 \\
\hline own & 0 & 0 \\
\hline \multicolumn{3}{|l|}{ Roughage sources } \\
\hline Teff straw & 24 & 50.0 \\
\hline Grass hay & 6 & 12.5 \\
\hline Teff and wheat straw & 5 & 10.4 \\
\hline Teff straw and hay & 6 & 12.5 \\
\hline All & 7 & 14.6 \\
\hline Total & 48 & 100 \\
\hline \multicolumn{3}{|l|}{ Source of concentrate feeds } \\
\hline Agro industrial by-products ${ }^{1}$ & 41 & 85.4 \\
\hline Sorghum and maize grain & 7 & 14.6 \\
\hline \multicolumn{3}{|l|}{ Non-conventional feeds } \\
\hline Poultry feces & 3 & 6.25 \\
\hline Not used & 47 & 93.75 \\
\hline \multicolumn{3}{|l|}{ Growth promoters } \\
\hline Yes & 0 & 0 \\
\hline no & 48 & 100 \\
\hline \multicolumn{3}{|c|}{ pre-mixes (vitamin and mineral mix) use } \\
\hline yes & 0 & 0 \\
\hline no & 48 & 100 \\
\hline \multicolumn{3}{|l|}{ Water } \\
\hline Ad libitum & 48 & 100 \\
\hline Restricted & 0 & 0 \\
\hline
\end{tabular}

${ }^{1}$ Agro-industrial by-products $=$ Wheat bran, wheat middlings, whole cotton seed, cotton seed cake, noug seed cake, Soybean, lentil bran, haricot bean bran, haricot bean shorts, lentil shorts; $\mathrm{N}$ = number of commercial feedlot. reported that crop residues from cereals used as source of roughages for livestock feeding. In this study, teff straw was usually utilized by most of feedlot operators whereas the other roughages were rarely utilized in the study areas (Table 5). According to the information obtained from the fatteners the type of roughage used was directly related with cost effectiveness and availability of the roughage near to fattening units. Discussants noted that the availability of crop residues is closely related to the farming system, type of crops produced and intensity of cultivation.

\subsubsection{Agro Industrial By-Products}

Agro-industrial by-products widely used as source of livestock feed include those resulting from flour mills, oil processing factories, and sugar factory. The agroindustrial by-products (concentrate) feeds are used as energy and/or protein. Accordingly, they classified as energy or protein sources or sources of both energy and protein.

The source of concentrate feeds commonly used in the study area includes wheat bran, wheat middling, whole cotton seed, cotton seed cake, noug seed cake, soybean, lentil bran, haricot bean bran, haricot bean shorts, and lentil shorts. However, sorghum and maize grains were utilized by few farms as shown in Table 6. Similarly, the grains and agro-industrial by products were utilized as concentrate feed sources in feedlot industries [7,11-13]. Most feedlot farms used wheat bran, wheat shorts, whole cotton seed and its cake noug seed cake, soybean and wheat middling; however, sorghum and maize grains were utilized as an ingredient to the compound concentrate feed by few farms (Table 5). 
Table 6. Feeding procedures in commercial feedlot.

\begin{tabular}{|c|c|c|}
\hline $\begin{array}{l}\text { Is roughage provided every } \\
\text { day/throughout fattening }\end{array}$ & $\mathrm{N}$ & Percent \\
\hline Yes & 48 & 100 \\
\hline No & 0 & 0 \\
\hline \multicolumn{3}{|l|}{ Daily feeding frequency } \\
\hline twice & 35 & 72.9 \\
\hline three & 13 & 27.1 \\
\hline \multicolumn{3}{|c|}{ Is feed given based on body weight } \\
\hline yes & 0 & 0 \\
\hline no & 48 & 100 \\
\hline \multicolumn{3}{|c|}{ Is concentrate every day/throughout fattening } \\
\hline yes & 46 & 95.8 \\
\hline no & 2 & 4.2 \\
\hline \multicolumn{3}{|l|}{ Roughage provision } \\
\hline Ad libtum & 34 & 70.8 \\
\hline restricted & 14 & 29.2 \\
\hline Total & 48 & \\
\hline \multicolumn{3}{|l|}{ Daily feeding procedure } \\
\hline Concentrate-roughage mix & 1 & 2.1 \\
\hline Roughage-concentrate mix & 47 & 97.9 \\
\hline \multicolumn{3}{|l|}{ Roughage treatment } \\
\hline yes & 0 & 0 \\
\hline no & 48 & 100 \\
\hline \multicolumn{3}{|l|}{ Ration formulation } \\
\hline yes & 0 & 0 \\
\hline no & 48 & 100 \\
\hline \multicolumn{3}{|c|}{ Ratio of concentrate to roughage known } \\
\hline Yes & 0 & 0 \\
\hline no & 48 & 100 \\
\hline \multicolumn{3}{|l|}{ Amount of concentrate $(\mathrm{kg})$} \\
\hline $3 \mathrm{~kg}$ & 3 & 6.2 \\
\hline $5-7 \mathrm{~kg}$ & 5 & 10.4 \\
\hline $8-10 \mathrm{~kg}$ & 31 & \\
\hline $11-12 \mathrm{~kg}$ & 9 & 18.8 \\
\hline total & 48 & 100 \\
\hline
\end{tabular}

$\mathrm{N}=$ number of respondents.

\subsubsection{Non Conventional Feeds and Other Feed Stuffs}

These are assumed to be off value and wastes by most of the producers. Accordingly, 93.75\% of feedlot enterprises did not used the non-conventional feed stuffs though $6.25 \%$ feed lot farms included as one of feed resources for fattening. Accordingly, poultry feces were used as protein source in some farms as shown in Table 5.

Minerals such as major minerals ( $\mathrm{Ca}$ and $\mathrm{P}$ ) as well as trace minerals (cobalt, copper, iodine, iron, manganese and zinc) are important component of the feed in growing and finishing steers [7,14]. In the study, only salt was mixed in feeder ration in all farms as a mineral supple- ment. Vitamins were not also used in all feedlot farms in the study area. Though, vitamins like, A, D and E are widely utilized in commercial farms for better performance [7].

Water is one of the indispensable nutrients in feedlot industries. It is available as free choice every day throughout fattening in all farms in the study area. Synthetic steroid hormones are known for better efficiency and faster growth of livestock. In all feedlot, farms synthetic hormones were not used. This could be due to lack of familiarities of fatteners with the implants and their application, notion of producing organic product and the risks in wellbeing of the consumers, that is the issue of wholesomeness of the product.

\subsection{Feeding Procedure in Commercial Feedlots}

With regards to feeding procedure, initially animals were not weighed and feed was provided by common sense. Moreover, the ratio of concentrate to roughage was not known in all commercial farms as show in Table 6. The daily feeding frequency followed by almost all commercial farms was twice and only few farms were followed three times of feeding. In addition, almost all farms followed the classical daily feeding procedure that is initially gave the roughage and then concentrate on the top of roughage whereas; the reverse procedure was noted by only one farm. Generally, all farms provided roughage and concentrate at mix which is uncommon in the trials usually conducted in stations.

$70.8 \%$ of feedlot owners provide roughage as an ad libtum. However, in $29.2 \%$ of farms roughage offered was restricted. As a common procedure, in $72.9 \%$ of commercial farms roughage was provided twice a day at the morning and evening before provision of concentrate in both cases. This result also noted that by all feedlot farms no attempt had been done to improve the nutritional value of the roughage feeds.

All feed lot farms provided concentrate twice a day. Usually all farms offered concentrate mix, though the ratio of mixing of ingredients was so variable or not uniform across the farms. Concentrate was offered every day throughout the fattening period. The amount of concentrate mix provided was different from farm to farm as shown in Table 6. From that reason, most feed lot farms offered $9-10 \mathrm{~kg}$ of concentrate mix per head/day followed by 7 - $8 \mathrm{~kg}$. Whereas, few feedlot farms reported that least amount of daily concentrate was offered (3 - 4 $\mathrm{kg} /$ head/day) as reveled in Table 6 .

Feed was given by common sense in all feedlot farms without considering whether the traditional ration meets the nutritional requirement of feeder or not. Therefore, generally livestock were provided feed without knowing the age and body weight of the animal by conventional 
agreement. This could be resulted because lack of skilled personnel or particularly nutritionist in the farm to improve the profitability and sustainability of the business, thus, involvement of skilled personnel has to be planned for the future as one of the requirement.

\subsection{Housing Facilities of Commercial Feedlots}

In all commercial farms, fattening animals were fed and drunk in group because there had no compartment with a specific dimension in both feeding and watering troughs during physical observation of the farms. Most feeding troughs were made up of woody materials but few from cement concrete.

Furthermore, most of shelters were exposed to sun, rain and wind without over head shed but, there were sheds for watering and feeding troughs. In few farms isolated house had not available for patient livestock. Moreover, in all feedlot farms there were no drainage systems and the out late for the waste materials produced.

\subsection{Constraints of Commercial Feedlots}

Challenges of commercial fattening are listed based on their order of importance as shown in Table 7. Most of feedlot farms noted that market was considered as the most challenging in failure or success of the enterprise. This could be due to unorganized market systems in both local and export markets. In addition, most of the existed markets as a whole and export market in particular lacked consistency and continuity. Usually feedlot owners or investors were considered as the only role player in identification and searching of market for the finished livestock. Feedloters also noted conflicts in the region and informal or smuggling trade of livestock throughout the border of the country had significant effect on marketing of the fattened animals. Similar to this study, [9,15-17] reported several constraints violating the smooth flow livestock market from the producer to the feedlots, processing, and consumption points in Ethiopia.

Feed was the 2nd limiting factor followed by type or quality of livestock coming to feedlot and water shortage as shown in Table 7. All discussants argued that feed availability was season dependent and lead to variation in cost between seasons. From that reason, ample amount of hey is produced starting from end of October to beginning of March and with in which the price of hay is reasonable. Whereas, starting from April to September the availability of hay decreased and cost of hay/bale is very high.

Similarly, the availability of concentrate decreased staring from March to the end of June. Because at that time there is shortage of pasture and crop resides and leads to
Table 7. Ranking of constraints for commercial fattening.

\begin{tabular}{lccccccc}
\hline $\begin{array}{l}\text { List of } \\
\text { constraints }\end{array}$ & Total & 1st & 2nd & 3rd & 4th & 5th & 6th \\
\hline Market & 48 & 32 & 15 & 0 & 1 & 0 & 0 \\
Feed & 41 & 5 & 11 & 12 & 2 & 11 & 13 \\
$\begin{array}{l}\text { Type of } \\
\text { livestock }\end{array}$ & 35 & 7 & 2 & 13 & 5 & 0 & 8 \\
Water shortage & 27 & 0 & 2 & 5 & 10 & 0 & 15 \\
Disease & 20 & 1 & 2 & 0 & 8 & 9 & 0 \\
Skilled personnel & 19 & 0 & 0 & 11 & 0 & 1 & 7 \\
\hline
\end{tabular}

high competition between farmers and feedlot operators in purchasing of concentrate to their livestock. Whereas, almost all feedlot farms noted that diseases and skilled manpower had least effect on commercial fattening.

Hence, to overcome the challenges, almost all fatteners declared that Ethiopian Commodity Exchange (ECX) should be developed for livestock marketing like that of other commodities in the country and create a link starting from producer to the end of consumer. Furthermore, feedloters suggested that pastoralists or producers should be supplied that should be supplied with all the necessary services and improvement strategies in an organized way at their locality to ensure sustainable supply of livestock to the industries. In addition, development of quarantine has to be available in all livestock source areas.

\section{CONCLUSION}

This study revealed that Borona cattle were the most preferred cattle breed, compared to the rest of cattle to the export market. However, all cattle breeds were equally accepted by domestic market. Pastoralist was the potential suppliers of feeder animal followed by small holders to feed lot industries in the study area and the market system was unorganized and dominated by informal and unprofitable transactions. The major feed resources used in commercial feedlot include roughage feeds, agro-industrial by products and grains in few farms. Non-conventional feed stuffs were also used by few farms as feed for fattening. Vitamins and mineral supplementations were not often available except common salt in all feedlot rations. Study confirmed that, almost all fattening farms finish the bull for about an average of 3 - 4 months and followed three times of finishing per year. The present study suggested that, to develop the sector and bring change, Ethiopian Commodity Exchange (ECX) should incorporate livestock and their products in the system to develop livestock marketing sector like that of other commodities in the country and create a link staring from producer to the end consumer. Finally, study suggested that the government should be hand-in-hand with the investors to organize market in a very short run to eradicate the informal market and the 
smuggle trading in order to ensure successful development of the sector and secure food security in the country.

\section{ACKNOWLEDGEMENTS}

The Ethiopian Ministry of Education through Haramaya University is duly acknowledged for sponsoring the study. I would like to thank Dr. kimia Quarantine Head of Animal Section for her assistance and facilitation during survey work.

\section{REFERENCES}

[1] CSA (Central Statistical Authority) (2010) Ethiopian agricultural sample survey 2010, Vol. II. Report on Livestock and Livestock Characteristics, Bulletin, 468.

[2] CSA (Central Statistical Authority) (2004) Ethiopian agricultural sample survey 2004, Vol. II. Report on Livestock and Livestock Characteristics, Bulletin, 468.

[3] SPSS, (Statistical Package for Social Sciences) (2003) SPSS Base 10.0. Application Guide. SPSS Inc.

[4] Asfaw, N., Shahidur, R. and Berhanu, G. (2011) Livestock production and marketing, working paper number 26, Ethiopia Strategy Support Program II, Ethiopia.

[5] Aynalem, H., Workneh, A., Noah, K., Tadelle, D. and Azage, T. (2011) Breeding strategy to improve Ethiopian Boran cattle for meat and milk production. IPMS (Improving Productivity and Market Success) of Ethiopian Farmers Project Working Paper 26. Nairobi, ILRI.

[6] Tsegay, T. (2012-2013) Consumer perceptions and preferences of meat types in Harar and Haramaya towns, Ethiopia. Journal of Microbiology, Biotechnology and Food Sciences, 2, 959-969.

[7] Leupp, J.L., G.P., Lardy, M.L., Bauer, K.K., Karges, M.L., Gibson, J.S., Caton and Maddock, R.J. (2009) Effects of dried distillers grain with soluble on growing and finishing of steer intake, performance, and carcass characteristics, color and sensory attributes. North Dakota State University (NDSU) Beef feedlot research report.

[8] Ministry of Agriculture and Rural Development (MoARD) (2007) A comprehensive plan for supporting the meat export industry Part I, Addis Ababa, Ethiopia.
[9] Negassa, A., and Jabbar, M. (2008) Livestock ownership, commercial off-take rates and their determinants in Ethiopia. Research Report 9. Nairobi, Kenya: ILRI (International Livestock Research Institute).

[10] Solomon, B, Solomon, M. and Alemu, Y. (2008) Potential use of crop residues as livestock feed resources under smallholder farmer conditions in Bale Highlands of Ethiopia. Tropical and Subtropical Agro ecosystems, ano/ volume 8, numero 001. Universidad Autonoma de Yucatan, Mexico, 107-114

[11] Yayneshet, T. (2010) Feed Resources Availability in tigray region, northern Ethiopia, for production of export quality meat and livestock. Ethiopia Sanitary \& Phytosanitary Standards and Livestock \& Meat Marketing Program (SPS-LMM) Report. 77pp.

[12] US Department of Agriculture (USDA) and Economic Research Service. (1985) Feed: Outlook and situation report. US Government Printing Office, Washington DC, December 1985.

[13] Roy, K.H. and Robert, K.M. (1994) Value and quality assurance by-product feeds. Cattle producer's library, US Department of Agriculture, Coperative Extension Service.

[14] Secrist, D.S., Owens, F.N. and Gill, D.R. (1997) Effects of Vitamin E on performance of feedlot cattle: A review. The Professional Animal Scientist, 13, 47-54.

[15] Aklilu, Y. (2002) An audit of the livestock marketing status in Kenya, Ethiopia and Sudan. Volume I. Community-Based Animal Health and participatory Epidemiology Unit. Pan African Program for the Control of Epizootics, Organization of African Unity/Interafrican Bureau for Animal resources.

[16] Hurissa, B., and Eshetu, J. (2003) In: Jobre, Y. and Gebru, G., Eds., Challenges and opportunities of livestock marketing in Ethiopia: Proceedings 10th Annual conference of the Ethiopian Society of Animal Production (ESAP), Challenges and Opportunities of Livestock Marketing in Ethiopia, Addis Ababa, Addis Ababa: ESAP, Ethiopia, August 22-24, 2002, pp. 1.-14.

[17] Hurissa, B. and Legesse, G. (2008) Livestock marketing in Ethiopia: Development opportunities and constraints. A paper presented on a Workshop Organized by Ministry of Federal Affairs and Afar Regional State. August 3-4, 2008, pp. 9-12. 